\title{
Ouder-kind relaties en sociaal-emotionele problematiek in de volwassenheid
}

\author{
Een prospectief onderzoek van geboorte tot volwassenheid
}

\author{
Geertjan Overbeek • Ad Vermulst • Häkan Stattin • \\ Thao Ha $\cdot$ Rutger C. M. E. Engels
}

\begin{abstract}
Samenvatting In dit onderzoek zijn verbanden onderzocht tussen de ouder-kind relatie en de sociaal-emotionele ontwikkeling gedurende de levensloop. Er werden gegevens gebruikt van 212 personen die van hun geboorte tot en met hun zevenendertigste jaar zijn gevolgd. SEM-analyses maakten duidelijk dat een lagere affectieve kwaliteit van ouder-kind relaties gerelateerd was aan een hoger niveau van conflict en lagere kwaliteit van communicatie met ouders in de adolescentie. Deze conflictueuze ouder-adolescent relaties waren op hun beurt weer verbonden met een lagere kwaliteit van partnerrelaties in de jongvolwassenheid, en meer ontevredenheid met het leven (maar niet depressie of angst) tijdens de middenvolwassenheid, op 37-jarige leeftijd.
\end{abstract}

De aard en kwaliteit van vroegkinderlijke ervaringen in het gezin worden doorgaans verondersteld van cruciaal belang te zijn voor de latere sociaal-emotionele ontwikkeling van kinderen. Meer in 't bijzonder wordt een lage affectieve kwaliteit van de ouder-kind band gezien als voorspeller voor een beperkte capaciteit in mensen om later bevredigende liefdesrelaties aan te gaan en te onderhouden (Ainsworth, 1989; Hazan \& Shaver, 1987), en als voorspeller voor de ontwikkeling van

Geertjan Overbeek, en, $(\square)$

Dr. G. Overbeek, dr. A. Vermulst, mevr. drs. T. Ha en prof. dr. R.

C. M. E. Engels zijn verbonden aan de Radboud Universiteit Nijmegen.Prof. dr. H. Stattin is verbonden aan de Örebro Universiteit te Örebro, Zweden.Contactadres: Geertjan Overbeek, postbus 9104, 6500 HE Nijmegen, e-mail: mailto:g. overbeek@pwo.ru.nlDit artikel is een bewerking van een artikel dat binnenkort in Developmental Psychology zal verschijnen. zowel internaliserend als externaliserend probleemgedrag (Dozier, Stovall, \& Albus, 1999).

Eén van de veronderstelde theoretische mechanismen achter deze zienswijze is dat, gebaseerd op de vroegkinderlijke ervaringen met ouders in het gezin, kinderen cognitief-affectieve representaties ontwikkelen van de nabijheid en affectieve kwaliteit die kenmerkend zijn voor intieme relaties met anderen (Bretherton \& Munholland, 1999). Deze representaties omvatten beelden van het zelf en van anderen, en omvatten specifieke verwachtingspatronen met betrekking tot interacties die zich kunnen voordoen in intieme relaties (Baldwin, 1992). De representaties worden verondersteld redelijk stabiel te zijn gedurende de tijd en onafhankelijk van context. Doordat deze representaties onze percepties en interpretaties van nieuwe (sociale) ervaringen structureren en sturen, blijven ze tijdens de levensloop van belang voor de sociale en emotionele ontwikkeling van het individu. Eerdere onderzoeken hebben, overeenkomstig met dit idee, laten zien dat een lage affectieve kwaliteit van ouder-kind relaties samenhing met angst (voor een metaanalyse zie Gerlsma, Emmelkamp, \& Arrindell, 1990), depressie (voor een overzicht zie Burbach \& Bourduin, 1986; MacKinnon, Henderson, \& Andrews, 1993), emotionele problemen (Overbeek, Vollebergh, Engels, \& Meeus, 2003;Steinberg, Lamborn, Darling, Mounts, \& Dornbusch, 1994), gebrek aan sociale vaardigheden in relaties met leeftijdgenoten en partners (Conger, Cui, Bryant, \& Elder, 2000; Engels, Finkenauer, Meeus, \& Dekovic, 2001), en onbevredigende partnerrelaties (Seiffge-Krenke, 2003).

Helaas hebben deze eerdere onderzoeken naar de 'effecten' van ouder-kind relaties zich uitsluitend gericht op de adolescentieperiode, of hebben ze zich uitsluitend gebaseerd op retrospectieve data over de vroegere band 
met ouders in de kindertijd. Retrospectieve gegevens kunnen echter ernstig vertekend zijn door herinneringseffecten (voor een overzicht zie Brewin, Andrews, \& Gotlib, 1993; Halverson, 1988). Slechts in een paar eerdere onderzoeken werd dit probleem omzeild door een prospectieve blik te werpen op de langetermijnverbanden tussen ervaringen met ouders in de kindertijd en sociaal-emotionele problematiek in de late adolescentie en volwassenheid. In bijvoorbeeld een onderzoek van Franz, McLelland en Weineberger (1991) werd een groep van 87 respondenten gevolgd vanaf de kindertijd (3 jaar) tot in de volwassenheid (34 jaar). De correlaties lieten een significant - maar zwak - direct verband zien tussen gevoelens van verbondenheid en warmte met vader en 'conventionele sociale ontwikkelingen' zoals een stabiel huwelijk. In een ander longitudinaal onderzoek door Flouri en Buchanan (2002) onder 2050 volwassenen uit de algemene bevolking werden geen directe verbanden onderzocht tussen ervaringen met ouders in de kindertijd en sociaal-emotionele problematiek in de volwassenheid. Echter, de auteurs vonden wél bewijs voor een verband tussen ouderlijke betrokkenheid op vijfjarige leeftijd van het kind en ouder-kind warmte en nabijheid tijdens de adolescentie, op zestienjarige leeftijd van het kind. Deze warmte en nabijheid waren vervolgens weer gerelateerd aan de ervaren kwaliteit van partnerrelaties op 33-jarige leeftijd. Ten slotte vond men in een ander onderzoek (Sroufe, Carlson, Levy, \& Egeland, 1999) dat een onveilige gehechtheid aan ouders in de kindertijd gerelateerd was aan hogere niveaus van zelfgerapporteerde pathologie op $171 \frac{1}{2}$-jarige leeftijd en een lagere competentie op de domeinen van werk, school, en relaties op 19-jarige leeftijd.

\section{De tussenliggende rol van ervaringen in de adolescentie}

Helaas leveren de longitudinale hierboven beschreven onderzoeken geen informatie over meerdere, opeenvolgende meetmomenten, nodig om ontwikkelingssequenties te kunnen onderzoeken. Dit is echter zeer belangrijk, aangezien het effect van negatieve ouder-kind interacties gedeeltelijk kan afhangen van latere ervaringen in bijvoorbeeld de adolescentie (zie Luthar, Cicchetti, \& Becker, 2000; O'Connor, 2003). Dit werd bijvoorbeeld gedemonstreerd in een onderzoek van Harris, Brown en Bifulco (1986). Zij vonden dat niet zozeer de vroege scheiding tussen kinderen en hun ouders leidt tot depressie op de volwassen leeftijd, maar dat het eerder ging om de onvoldoende mate van ouderlijke warmte en verzorging die vaak volgde op de scheiding tussen ouders en kind gedurende de verdere kindertijd en adolescentie. We zouden kunnen stellen dat het misleidend zou zijn om een direct causaal verband te onderzoeken van ouder-kind relaties in de kindertijd naar sociaal-emotionele problematiek in de volwassenheid, zonder daarbij precies te identificeren wat de onderliggende ontwikkelingssequentie is die dit verband kan verklaren.

Partnerrelaties in de adolescentie en (jong)volwassenheid

Meer in 't bijzonder moet bij zo'n ontwikkelingssequentie rekening worden gehouden met partnerrelaties in de adolescentie en (jong)volwassenheid. Het is duidelijk dat het relatieve belang van verschillende intieme relaties drastisch verandert gedurende de levensloop (BrooksGunn, Phelps, \& Elder, 1991). Tijdens bijvoorbeeld de adolescentie worden liefdesrelaties steeds belangrijker voor jongeren, en gedurende de late adolescentie en jongvolwassenheid worden gehechtheidsfuncties overgenomen van ouders door partners (Ainsworth, 1989; Hazan \& Shaver, 1987). De onderliggende aanname is hierbij dat een schadelijke ouder-kind band leidt tot patronen van zelf-en-ander percepties en emotieregulatie die het moeilijk maken voor een individu om bevredigende partnerrelaties te kunnen aangaan en onderhouden (Davila, Bradbury, \& Fincham, 1998). Daarbij komt dat een lage kwaliteit van ouder-kind relaties ertoe leidt dat mensen een voorkeur ontwikkelen voor bepaalde sociale contexten boven andere (Collins, Cooper, Albino, \& Allard, 2002). Bijvoorbeeld: harde disciplinering door ouders of sterk verwaarlozend opvoedingsgedrag kan er bij kinderen toe leiden dat zij zichzelf gaan zien als mensen die geen warmte of liefde waard zijn en anderen gaan zien als emotioneel onbereikbaar. Dit vergroot de mogelijkheid dat mensen, als adolescenten of volwassenen, partners uitkiezen die ook geen warm of ondersteunend gedrag vertonen, wat weer leiden kan tot negatieve interacties en negatief affect in de partnerrelatie.

Gedurende de late adolescentie worden partnerrelaties één van de meest belangrijke bronnen van kameraadschap en intimiteit (Furman \& Buhrmester, 1992) en zullen de meeste mensen een hoog niveau van interafhankelijkheid en nabijheid ervaren ten opzichte van hun partner (Laursen \& Williams, 1997). Partnerrelaties worden daarmee steeds belangrijkere voorspellers voor emotioneel welzijn in de volwassenheid. Zij determineren de context waarin thema's van seksualiteit en intimiteit worden behandeld: niet in staat zijn om een bevredigende partnerrelatie aan te gaan en te onderhouden kan samenhangen met sociale isolatie en lagere niveaus van geestelijke gezondheid (Erikson, 1963). Talrijke onderzoeken hebben verder ook bewijs geleverd voor het feit dat onbevredigende partnerrelaties en huwelijken verbonden zijn aan de ontwikkeling van subklinische niveaus van emotionele problematiek zoals depressieve stemmingen en 
psychische stress (bv. Cramer \& Donachie, 1999; Horowitz, McLaughlin, \& White, 1998). Concluderend kunnen we stellen dat een lage kwaliteit van ouder-kind relaties op jonge leeftijd het risico doet toenemen op onbevredigende partnerrelaties in de jongvolwassenheid, en dat die op hun beurt weer kunnen leiden tot ontevredenheid en teleurstellingen op romantisch vlak en tot emotionele problemen in de volwassenheid.

\section{Het huidige onderzoek}

Het onderzoek richtte zich op langetermijn-, prospectieve verbanden tussen de affectieve kwaliteit van de ouder-kind band en sociaal-emotionele problematiek in de volwassenheid (geoperationaliseerd als partnerrelaties van lage kwaliteit, angst, depressieve stemmingen, en ontevredenheid met het leven), in een algemene steekproef van 212 Zweedse individuen. Met behulp van SEM-technieken (Structural Equation Models), toetsten we een theoretisch model, waarin $(A)$ een lage kwaliteit van ouder-kind relaties gerelateerd was aan conflict en een lage kwaliteit van communicatie tussen ouders en kinderen in de adolescentie, $(B)$ ouder-adolescent conflict en een lage kwaliteit van communicatie gerelateerd waren aan een lage kwaliteit van partnerrelaties in de jongvolwassenheid, en $(C)$ een lage kwaliteit van partnerrelaties in de jongvolwassenheid voorspellend zou zijn voor sociaal-emotionele problemen in de midden-volwassenheid (zie figuur 1).

Zoals te zien is in figuur 1, zijn voor sommige concepten extra voorspellers meegenomen. Bijvoorbeeld, in onze voorspelling van de kwaliteit van de partnerrelatie op 25-jarige leeftijd namen we ook 'gevoelens ten aanzien van het andere geslacht' mee op 15-17-jarige leeftijd, omdat we - los van ons theoretisch model - daar een belangrijke invloed van verwachtten. Hetzelfde gold voor onze voorspelling van angst, depressiviteit, en ontevredenheid met het leven op 37-jarige leeftijd. In het model worden deze concepten niet alleen voorspeld door de kwaliteit van de partnerrelatie op 25-jarige leeftijd, maar ook door eerdere niveaus van emotionele problematiek op 25-jarige leeftijd.

\section{Methode}

Steekproef en procedure

De respondenten vormden een willekeurige steekproef van kinderen geboren tussen 1955 en 1958 in Solna, een buitenwijk van Stockholm in Zweden. Elke vierde zwangere moeder die een bezoek bracht aan de Solna kliniek voor prenatale zorg werd gevraagd deel te nemen aan een

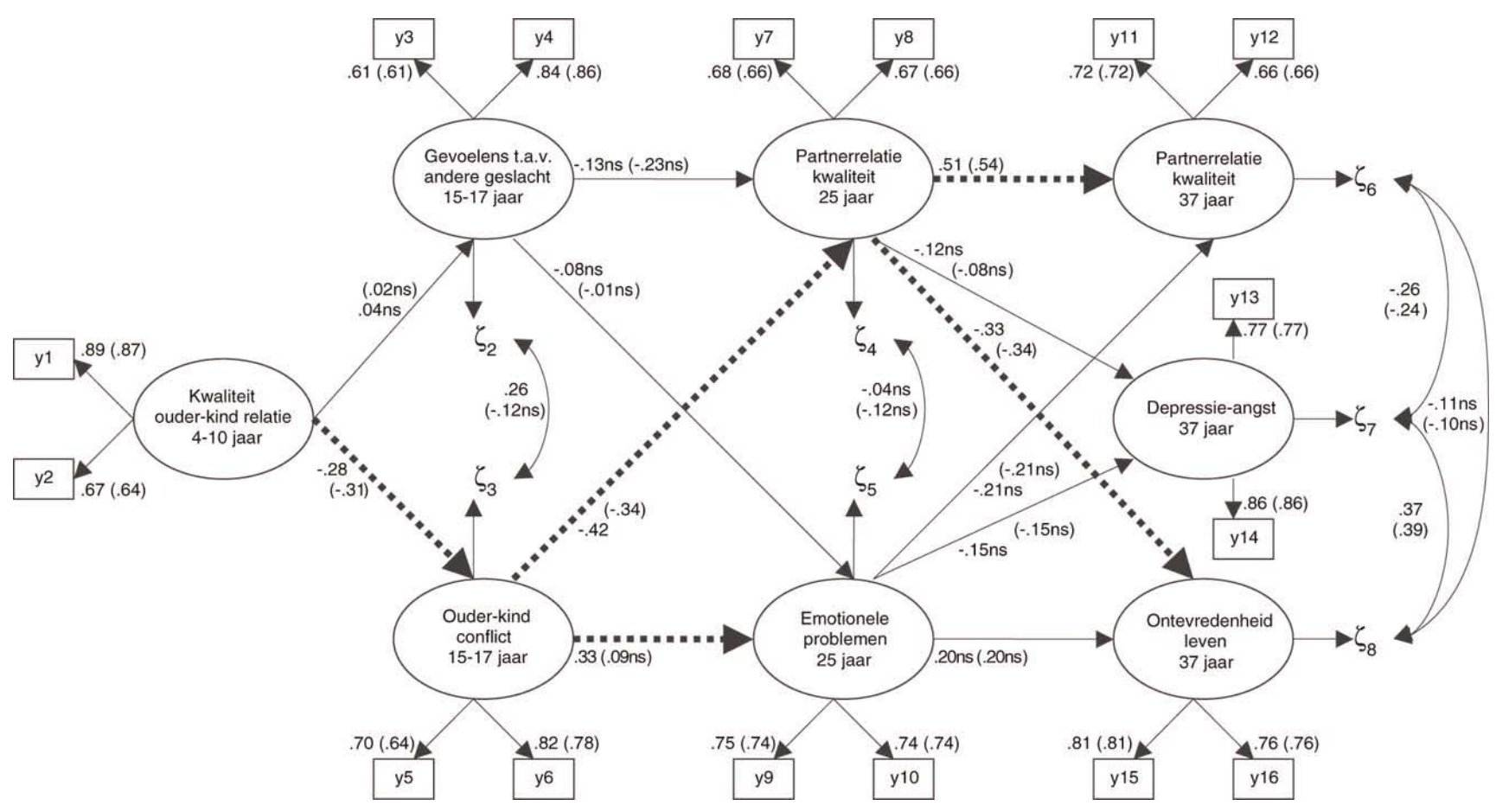

Figuur 1 Maximum likelihood schattingen voor structurele modellen voor moeder-kind relaties en vader-kind relaties Schattingen tussen haakjes zijn voor vader-kind relaties. $?^{2}(95)=162.47, \mathrm{CFI}=.900$, en RMSEA $=.058($ moeders $)$ en $?^{2}(95)=140.41, \mathrm{CFI}$ $=.923$, en RMSEA $=.048$ (vaders); ns staat voor niet significant. 
longitudinaal onderzoek. De huidige steekproef bestaat uit 212 deelnemers (122 mannen en 90 vrouwen) van 37 jaar oud. Voor details met betrekking tot de kenmerken van de steekproef zie Karlberg en anderen (1968). Slechts $3 \%$ van de moeders weigerde deel te nemen aan het onderzoek. Nadat ze hadden toegezegd om deel te nemen, werd de deelnemers verzocht om een telefonische afspraak te maken voor een bezoek aan de Solna kliniek voor een onderzoekssessie. Kinderen van moeders die deelnamen aan het onderzoek werden zes keer onderzocht gedurende het eerste jaar, twee keer tijdens het tweede jaar, en daarna jaarlijks tot aan hun achttiende levensjaar. In de jongvolwassenheid werden ook gegevens verzameld, namelijk op 21-jarige en 25-jarige leeftijd. De laatste follow-up werd uitgevoerd in 1992, toen de deelnemers 37 jaar oud waren.

Voor elk van de onderzoekssessies brachten de respondenten een bezoek aan de Solna kliniek; er werden geen thuisbezoeken gedaan. De opzet van de 'assessments' verschilde niet gedurende de meetmomenten. Om variaties in de chronologische leeftijd van de respondenten zo beperkt mogelijk te houden, werden de onderzoeken steeds uitgevoerd in een periode rond de verjaardag van iedere respondent ( \pm 14 dagen). De tests en interviews duurden tussen de vier en zes uur en vonden plaats in de Solna kliniek aan de Stockholm universiteit. Reis- en verblijfskosten van de respondenten en van hun partners werden betaald door de onderzoeksorganisatie. Elke deelnemer kreeg 500 Zweedse kronen $( \pm € 55,00)$ per keer. Er was zeer weinig uitval gedurende de tijd. Op 37-jarige leeftijd nam $91 \%$ van allen die nog steeds in leven waren $(8$ personen stierven tijdens de looptijd van het onderzoek) weer deel aan het onderzoek.

Van alle 185 respondenten die deelnamen aan de laatste onderzoekssessie op 37-jarige leeftijd gaven $131(71 \%)$ aan dat zij op dat ogenblik in een huwelijk of samenwoonrelatie betrokken waren (op 25-jarige leeftijd was dit bij 55\% het geval). Voor de duidelijkheid zullen we in dit artikel steeds spreken over partnerrelaties waarmee we zowel de huwelijks- als samenwoonrelaties bedoelen. De gemiddelde duur van de partnerrelaties van de respondenten was 6,2 jaar op 37-jarige leeftijd.

Voor het huidige onderzoek gebruikten we de gegevens uit de kindertijd waarbij gegevens jaarlijks werden verzameld (op 4-, 5-, 6-, 7-, 8-, 9-, en 10-jarige leeftijd). Daarnaast richtten we ons op jaarlijks verzamelde gegevens uit de 15-17-jarige leeftijdsfase. Ten slotte gebruikten we gegevens uit de jongvolwassenheid (25jarige leeftijd) en uit de middenvolwassenheid (37-jarige leeftijd). Voor de gegevens uit de kindertijd baseerden we ons op informatie van de ouders uit de gestructureerde interviews. Ouders vulden vragenlijsten in en werden geïnterviewd over de relatie en interacties met hun kinderen. In de adolescentie, jongvolwassenheid, en middenvolwassenheid werden de kinderen zelf geïnterviewd over onder andere hun dagelijkse interacties met ouders en leeftijdgenoten, waaronder die van het andere geslacht. Ten slotte keken we in de jong- en middenvolwassenheid ook naar het welzijn en de kwaliteit van de op dat moment aanwezige partnerrelaties van de respondenten.

\section{Meetinstrumenten}

Informatie met betrekking tot de meetinstrumenten (onder andere voorbeelditems en Cronbachs alfa-coëfficiënten) staat ook weergegeven in tabel 1 .

\section{Kwaliteit van de ouder-kind relatie (4-10 jaar)}

De algemene affectieve kwaliteit van de ouder-kind band werd nagegaan met een gestructureerd interview met de moeder van het kind. Deze gegevens waren beschikbaar voor de kindertijd, van 4-10 jaar. Aparte beoordelingen werden gegeven door de moeder met betrekking tot de moeder-kind band en vader-kind band. De beoordelingen werden gegeven op een driepuntsschaal die liep van 'slecht' naar 'redelijk' tot en met 'goed'. Voor het doel van het huidige onderzoek werden de scores gesommeerd over de 4-10 jaarsperiode; dit werd apart gedaan voor de moeder-kind gegevens en de vader-kind gegevens. Respondenten hadden een score op deze maat als ze tijdens ten minste vier meetrondes een score toegekend hadden gekregen. De gemiddelde jaar-tot-jaar Pearson correlatie was $.60(p<.001)$ voor de vader-kind relatie en $.42(p<$ $.001)$ voor de moeder-kind relatie, wat laat zien dat er in de totale steekproef een gemiddeld tot hoog niveau van stabiliteit was in de affectieve kwaliteit van de ouder-kind band.

\section{Ouder-adolescent conflict (15-17 jaar)}

Ook de mate van conflict en de kwaliteit van de communicatie tussen ouders en kinderen werden apart gescoord voor moeders en vaders. Tijdens de adolescentiefase konden de jongeren antwoord geven op drie items, die werden gescoord op verschillende antwoordschalen met betrekking tot communicatie en conflict met ouders. Items over de communicatie met ouders - twee items per meetmoment - hadden betrekking op de mate waarin respondenten het gevoel hadden dat ze konden praten met hun ouders over intieme of gevoelige thema's ('Ik kan altijd terecht bij mijn moeder/vader voor belangrijke zaken'). De antwoordschaal varieerde van ' 1 . nee, niet erg vaak' tot en met '3. ja, ik kan altijd bij haar/hem 
Tabel 1 Voorbeelditems en Cronbachs alfa-betrouwbaarheden

\begin{tabular}{|c|c|c|c|c|}
\hline $\begin{array}{l}\text { Concept tijdens een } \\
\text { leeftijdsfase }\end{array}$ & Voorbeelditem & Antwoordschalen & $\begin{array}{r}\text { Aantal } \\
\text { items } \\
\end{array}$ & $\begin{array}{r}\text { Cronbachs } \\
\text { alfa } \\
\end{array}$ \\
\hline Ouder-kind kwaliteit 4-10 & $\begin{array}{l}\text { 'Wat is de kwaliteit van de relatie met moeder } \\
\text { (vader)?' }\end{array}$ & $1-3$ & 14 & .86 \\
\hline $\begin{array}{l}\text { Gevoelens t.a.v. andere } \\
\text { geslacht } 15\end{array}$ & $\begin{array}{l}\text { 'Ik maak me zorgen dat jongens (meisjes) me } \\
\text { uitlachen.' }\end{array}$ & $1-5$ & 7 & .74 \\
\hline Ouder-kind conflict $15-17$ & $\begin{array}{l}\text { 'Wat is het niveau van conflict met je vader } \\
\text { (moeder)?' }\end{array}$ & $1-5$ & 6 & .73 \\
\hline Partnerrelatie kwaliteit 25 & $\begin{array}{l}\text { 'Hebben jij en je partner gemeenschappelijke } \\
\text { interesses?' }\end{array}$ & $1-5$ & 5 & .68 \\
\hline Emotionele problemen 25 & $-{ }^{a}$ & $1-5$ & 2 & .71 \\
\hline Partnerrelatie kwaliteit 37 & 'Kunnen jij en je partner goed met elkaar overweg?' & $1-5$ & 4 & .75 \\
\hline Ontevredenheid leven 37 & $\begin{array}{l}\text { 'Als ik terugkijk op mijn leven, ben ik behoorlijk } \\
\text { tevreden.' }\end{array}$ & $1-2$ & 8 & .73 \\
\hline Depressie 37 & $\begin{array}{l}\text { 'Hoe vaak heb je je eenzaam gevoeld de afgelopen } \\
\text { maand?' }\end{array}$ & $1-6$ & 5 & .91 \\
\hline Angst 37 & $\begin{array}{l}\text { 'Hoe vaak heb je je gespannen gevoeld de afgelopen } \\
\text { maand?' }\end{array}$ & $1-6$ & 10 & .83 \\
\hline
\end{tabular}

${ }^{a}$ Er is geen voorbeelditem opgenomen voor het concept 'Emotionele problemen 25', aangezien het hier ging om observaties van moederkind interacties.

terecht'. Items over conflicten met ouders - één item per meetmoment - hadden betrekking op de waargenomen niveaus en intensiteit van conflict ('Wat is het niveau van conflict met je vader/moeder?'). De antwoordschaal varieerde hier van ' 1 . nooit, of heel zelden conflicten' tot en met '5. vaak conflicten, kunnen niet met elkaar overweg, vaak boos op elkaar'. De jaar-tot-jaar stabiliteit van conflict met moeder was $.53(p<.001)$ en van communicatie met moeder was $.56(p<.001)$. Met betrekking tot de vader-kind relatie was de gemiddelde jaar-tot-jaar stabiliteit van conflict .49 $(p<.001)$ en voor communicatie $.35(p<.001)$.

Gevoelens ten aanzien van het andere geslacht (15-17 jaar)

Zorgen over de eigen relatie met het andere geslacht in de adolescentie namen we op in onze analyses om te kunnen controleren voor autoregressie met betrekking tot het concept 'relaties met personen van het andere geslacht' van de adolescentie tot de jongvolwassenheid (zie figuur 1). Een totaal van zeven items werd gedestilleerd van een 65-item 'zorgen-vragenlijst', die werd afgenomen bij adolescenten op 15-jarige leeftijd (zie ook Möller \& Stattin, 2001). De items waren 'Me niet op mijn gemak voelen in het gezelschap van leeftijdgenoten van het andere geslacht', 'Jongens/meisjes lachen me uit', 'Een kind krijgen voordat ik kan trouwen' (voor meisjes), 'Een meisje zwanger maken' (voor jongens), 'Hoe ver je mag gaan als je zoent of vrijt met een jongen/ meisje', 'Dat jongens/meisjes me naakt zien', en 'Niet genoeg weten over seks'. De antwoordschaal liep van ' 1 . maak ik me geen zorgen over' tot en met '5. maak ik me veel zorgen over'.

Kwaliteit partnerrelatie (25 en 37 jaar)

Zowel in de jongvolwassenheid ( 25 jaar) als middenvolwassenheid ( 37 jaar) werd respondenten gevraagd of ze op dit ogenblik een partnerrelatie hadden. Als 'ja' werd geantwoord, werd de respondenten gevraagd om enkele vragen te beantwoorden over de kwaliteit van hun huidige partnerrelatie. Op 25-jarige leeftijd werd de kwaliteit van partnerrelaties gemeten met vijf items over conflict ('Heb je conflicten met je partner over religieuze zaken?' of 'Heb je conflicten met je partner over alcoholgebruik?'), gemeenschappelijke interesses ('Hebben jij en je partner gemeenschappelijk interesses?'), tevredenheid over seks ('Zijn jij en je partner goed aan elkaar aangepast in seksueel opzicht?') en communicatie ('Hoe communiceer je met je partner over meningsverschillen of tijdens ruzies?'). Deelnemers konden deze vragen beantwoorden op verschillende vijfpunts antwoordschalen. Op 37-jarige leeftijd werd de kwaliteit van de partnerrelatie gemeten op eenzelfde manier, met behulp van vier items gericht op de waargenomen kenmerken van de partner ('Hoe zou je je partner karakteriseren?'), gemeenschappelijke interesses ('Hebben jij en je partner gemeenschappelijke interesses die jullie delen?'), thuisatmosfeer ('Hoe zou je de atmosfeer bij jullie thuis omschrijven?') en tevredenheid in seksueel opzicht ('Zijn jij en je partner in seksueel opzicht goed aan elkaar aangepast?'). De respondenten konden hier 
wederom antwoord geven op verschillende vijfpunts antwoordschalen.

\section{Emotionele problemen (25 en 37 jaar)}

De maat voor emotionele problematiek op 25-jarige leeftijd was opgenomen in ons model om te kunnen controleren voor autoregressie met betrekking tot het concept 'onwelbevinden' van de jong- tot middenvolwassenheid (zie figuur 1). Meer in 't bijzonder verichtten getrainde psychologen bij de respondenten op 25-jarige leeftijd gedragsobservaties tijdens een interview, op basis waarvan bepaalde beoordelingen werden gegeven over het niveau van 'zenuwachtigheid' en 'emotionele stabiliteit'. Het interview duurde ongeveer drie uur en de psychologen waren getraind in het beoordelen van zowel de nonverbale als verbale uitingen van de deelnemers tijdens een interview. De beoordelingen varieerden voor wat betreft zenuwachtigheid van 1 tot en met $4(1=$ rustig, ontspannen, 4 = erg zenuwachtig, angstig) en voor wat betreft emotionele stabiliteit van 1 tot en met $5(1=$ stabiel, kan op zichzelf terugvallen, lijkt opgewassen tegen sterke emotionele druk, 5 = gedraagt zich angstig, psychosomatische tendenties, aanwijzingen voor geestelijke gezondheidsproblemen).

Op 37-jarige leeftijd werd emotioneel welzijn uitgebreider onderzocht met behulp van een Mental Health Inventory (MHI; Veit \& Ware, 1983) die bestond uit 38 items. Voor het doel van dit onderzoek werden die items uitgekozen die betrekking hadden op depressieve stemmingen ('Hoe vaak heb je je de afgelopen maand eenzaam gevoeld?'), en acht items die betrekking hadden op gevoelens van angst ('Heb je de afgelopen maand wel eens het idee gehad dat je erg gespannen was, of op 'knappen' stond?). Alle items werden beantwoord op verschillende zespunts antwoordschalen. Daarnaast keken we naar de algemene tevredenheid met het leven in respondenten, met acht items uit de Life Satisfaction Index (LSI; Neugarten, Havighurst, \& Tobin, 1961), bijvoorbeeld: 'Dit is de meest vervelende tijd uit mijn leven', en 'Als ik terugkijk op mijn leven ben ik behoorlijk tevreden'. Items van deze schaal werden gescoord op driepunts antwoordschaal die varieerde van ' 0 . niet mee eens' tot en met '2. mee eens'. Om de scores op de schaal een reflectie te laten zijn van ontevredenheid met leven, werden alle items op deze schaal gehercodeerd.

\section{Resultaten}

Allereerst onderzochten we voor alle variabelen mogelijke sekseverschillen. Behalve voor één van de variabelen (kwaliteit vader-kind relatie op 4-10 jarige leeftijd, met een hogere kwaliteit voor vader-dochter relaties dan voor vader-zoon relaties) vonden we geen sekseverschillen. Om mogelijke plafondeffecten in de data te onderzoeken bekeken we vervolgens of de verschillende variabelen normaal verdeeld zouden zijn. We vonden dat de verdeling van scores op alle variabelen, behalve voor de kwaliteit van de vader-kind relatie op de leeftijd van 4-10 jaar en de kwaliteit van de moeder-kind relatie van 4-10 jaar, ruwweg pasten in een standaard-normaal model. Voor de proporties van 'slechte', 'goede', of 'gemiddelde' scores op de schaal met betrekking tot de kwaliteit van de ouder-kind relatie, zie Stattin en Klackenberg (1992). De Pearson correlatiematrix voor de zeven hoofdvariabelen in het onderzoek staat in tabel 2. Deze matrix wordt gepresenteerd voor illustratieve doeleinden; de eigenlijke 'input' voor de SEM-analyses bestond uit een ruwe inputmatrix met 14 'parcels', twee voor elke latente variabele (de volledige correlatiematrix met alle indicatorvariabelen kan opgevraagd worden bij de eerste auteur).

Het aantal observaties voor elk van de correlaties varieert van $115(55 \%)$ tot $199(95 \%)$.

Tabel 2 Pearson correlaties en beschrijvende gegevens voor moeders (linksonder de diagonaal) en vaders (rechtsboven de diagonaal)

\begin{tabular}{|c|c|c|c|c|c|c|c|c|c|c|c|}
\hline & 1 & 2 & 3 & 4 & 5 & 6 & 7 & 8 & $M$ & $S D$ & $N$ \\
\hline 1. Kwaliteit ouder-kind relatie 4-10 & & .02 & $-.23 * *$ & .14 & -.05 & $.18^{*}$ & .00 & -.08 & 2.86 & .28 & 191 \\
\hline 2. Zorgen relatie andere geslacht 15 & -.03 & & -.03 & -.15 & .03 & -.10 & $.19^{*}$ & .09 & 1.87 & .68 & 163 \\
\hline 3. Ouder-kind conflict $15-17$ & $-.29 * * *$ & $.23 * *$ & & -.17 & .10 & $-.21 *$ & .01 & .14 & 2.82 & .69 & 161 \\
\hline 4. Kwaliteit partnerrelatie 25 & -.08 & -.15 & $-.29 * *$ & & -.10 & $.35 * * *$ & -.07 & $-.24 * *$ & 3.51 & .76 & 139 \\
\hline 5. Emotionele problemen 25 & -.13 & .03 & $.20^{*}$ & -.10 & & $-.20^{*}$ & .12 & $.18^{*}$ & 2.87 & .78 & 155 \\
\hline 6. Kwaliteit partnerrelatie 37 & .04 & -.11 & $-.19 *$ & $.35 * * *$ & $-.20^{*}$ & & $-.26 * * *$ & $-.25 * *$ & 4.72 & .63 & 147 \\
\hline 7. Depressie-angst 37 & -.01 & $.19 *$ & -.10 & -.07 & .12 & $-.26 * * *$ & & $.34 * * *$ & 1.90 & .56 & 184 \\
\hline 8. Ontevredenheid leven 37 & .03 & .09 & $.17 *$ & $-.24 * *$ & $.18^{*}$ & $-.25 * *$ & $.34 * * *$ & & 1.37 & .26 & 183 \\
\hline$M$ & 2.86 & 1.87 & 3.06 & 3.51 & 2.87 & 4.72 & 1.90 & 1.37 & & & \\
\hline$S D$ & .27 & .68 & .60 & .76 & .78 & .63 & .56 & .26 & & & \\
\hline$N$ & 198 & 163 & 165 & 139 & 155 & 147 & 184 & 183 & & & \\
\hline
\end{tabular}


Tabel 2 laat zien dat de kwaliteit van ouder-kind relaties in de kindertijd alleen significant verband houdt met de variabele 'ouder-kind conflict in de adolescentie'. Echter, jongeren die meer conflicten en een lage kwaliteit van communicatie met hun ouders rapporteerden, rapporteerden eveneens een lagere kwaliteit van partnerrelatie in de jong- en middenvolwassenheid, een hoger niveau van emotionele problemen in de jongvolwassenheid, en ook hogere niveaus van depressie, angst, en ontevredenheid met het leven tijdens de middenvolwassenheid. Verder lieten de resultaten zien dat een hogere kwaliteit van partnerrelatie tijdens de jongvolwassenheid negatief was gerelateerd aan ontevredenheid met leven in de middenvolwassenheid, en dat emotionele problemen in de jongvolwassenheid significant positief samenhingen met ontevredenheid met leven en een lage kwaliteit van de partnerrelatie tijdens de middenvolwassenheid.

\section{Multivariate (SEM) analyses}

Vanwege het relatief kleine aantal respondenten in het huidige onderzoek, werden geen multigroep analyses uitgevoerd met betrekking tot sekseverschillen. Wel werd het structurele model apart geschat voor de relaties moeder-kind en vader-kind. De correlatiegegevens werden vervolgens gebruikt als 'input' voor een uiteindelijke, meer stringente multivariaat-longitudinale analyse door middel van padanalyses met versie 3 (2004versie) van Mplus (Muthén \& Muthén, 2001). Figuur 1 laat het uiteindelijke padmodel zien, waarin zowel de autoregressies als 'cross-lagged' relaties staan gespecificeerd. De 'fit' van de modellen was adequaat te noemen $\left[?^{2}(95)=162.47\right.$, CFI $=.900$, RMSEA $=.058$ voor moeders en $?^{2}(95)=140.41, C F I=.923$, RMSEA $=.048$ voor vaders]. Er waren, zoals verwacht, geen directe significante verbanden tussen de kwaliteit van de ouder-kind relatie op de leeftijd van 4-10 jaar en uitkomstvariabelen op 25 en 37 jaar. Figuur 1 laat daarentegen zien dat zich een specifieke ontwikkelingssequentie ontvouwt van de kindertijd tot de volwassenheid. In de eerste stap van deze sequentie zijn hogere niveaus van kwaliteit van de ouder-kind relatie verbonden aan lagere niveaus van ouder-kind conflict in de adolescentie. In de volgende stap, van de adolescentie naar de jongvolwassenheid, vonden we dat hogere niveaus van ouder-kind conflict voorspellend waren voor een relatief laag niveau van de kwaliteit van de partnerrelatie tijdens de jongvolwassenheid, op 25-jarige leeftijd (over een periode van zeven jaar). Ten slotte werd duidelijk dat in de laatste stap, van de jongvolwassenheid naar de middenvolwassenheid (over een periode van twaalf jaar), er een verband was van een lage kwaliteit van de partnerrelatie naar hogere niveaus van emotionele problematiek (ontevredenheid met het leven) en naar latere onbevredigende partnerrelaties.

Opvallend was dat emotionele problematiek op 25jarige leeftijd alleen op trendniveau voorspellend was voor ontevredenheid met het leven en de kwaliteit van de partnerrelatie op 37-jarige leeftijd. Verder bleek dat gevoelens ten aanzien van het andere geslacht in de adolescentie geen longitudinale voorspeller waren voor de kwaliteit van de partnerrelatie en emotionele problematiek tijdens de jongvolwassenheid, op 25-jarige leeftijd. In dit model vonden we geen significant verband tussen de kwaliteit van de partnerrelatie in de jongvolwassenheid (op 25-jarige leeftijd) en depressie en angst in de middenvolwassenheid (op 37-jarige leeftijd). Met het door ons getoetste model konden we $36 \%$ van de variantie in scores op de kwaliteit van de partnerrelatie verklaren en $16 \%$ van de variantie in scores op ontevredenheid met het leven. Slechts 3\% van de variantie in scores op depressie of angst worden voorspeld aan de hand van dit specifieke model.

\section{Discussie}

Het huidige onderzoek maakt primair duidelijk dat er geen directe verbanden zijn tussen de lage kwaliteit van ouder-kind relaties in de kindertijd en depressieve stemmingen, angst, of ontevredenheid met het leven in de middenvolwassenheid. Negatieve ervaringen in de vroege kindertijd met ouders kunnen wel op een indirecte manier leiden tot emotionele problematiek in de volwassenheid, via een specifieke ontwikkelingssequentie. Een lage affectieve kwaliteit van ouder-kind relaties was gerelateerd aan een hoger niveau van conflict en een lage kwaliteit van communicaties tussen ouders en adolescenten, en deze conflictueuze ouder-kind interacties waren op hun beurt weer verbonden aan een lagere kwaliteit van partnerrelaties in de jongvolwassenheid. Ten slotte bleek dat over een periode van twaalf jaar zo'n lage kwaliteit van partnerrelaties voorspellend was voor ontevredenheid met leven (niet depressie of angst) tijdens de middenvolwassenheid, op 37-jarige leeftijd.

Alhoewel relaties tussen ouders en kinderen met een lagere affectieve kwaliteit niet geheel bepalen dat er later in de adolescentie conflictueuze of negatieve interacties tussen hen ontstaan, vergroot dit wel de kans op negatieve ouder-kind relaties tijdens deze leeftijdsfase. Door de invloed van ouder-kind interacties op latere ontwikkelingsstadia, kunnen vroegkinderlijke negatieve ervaringen een invloed hebben op de partnerrelaties die mensen later in hun leven aangaan en op de emotionele gezondheid van mensen in de jonge en middenvolwassenheid. Belangrijk is in dit verband om te benadrukken dat in de 
strikte zin van het woord deze resultaten ons niet toestaan om te spreken over mediatie-effecten of interveniërende variabelen (zie Baron \& Kenny, 1986). Echter, ze werpen wel licht op een ontwikkelingssequentie die loopt van de kindertijd naar de volwassenheid, die - zij het in stukjes en beetjes - gedestilleerd kon worden uit de wetenschappelijk literatuur (Collins e.a., 2002; O'Connor, 2003; Sroufe e.a., 1999).

Daarnaast geven de huidige resultaten bevestiging voor de hypothese van cross-relationele continuïteit van de late adolescentie naar de jongvolwassenheid: de resultaten laten zien dat respondenten die meer problemen ervoeren in hun relatie met hun ouders, ook een lagere kwaliteit van hun partnerrelatie rapporteerden. Er lijkt dus een zekere continuïteit te bestaan in de affectieve kwaliteit die mensen ervaren over verschillende soorten intieme relaties heen. Deze resultaten repliceren eerdere bevindingen en ze vergroten ons inzicht dat aanvankelijk uitsluitend was gebaseerd op onderzoeken naar het verband tussen 'ouder-partner verbanden' in de adolescentie en jongvolwassenheid (bv. Collins e.a., 2002), die hadden laten zien dat ouder-kind relaties een belangrijke voorspeller zouden kunnen zijn van de kwaliteit van de latere partnerrelatie. Met de huidige prospectief-longitudinale resultaten kunnen we nu stellen dat ouder-kind communicaties die conflictueus en van lage kwaliteit zijn in de adolescentie, een voorbode zijn voor een lage kwaliteit van partnerrelaties in de (jong)volwassenheid.

Alhoewel het verleidelijk zou kunnen zijn om deze resultaten te interpreteren alsof ze bewijs zouden kunnen geven voor een socialisatie-effect, hoeft dit niet het geval te zijn. Het is bijvoorbeeld zeer goed mogelijk dat kindeffecten grotendeels de gevonden relaties verklaren. Te hoge niveaus van ouderlijke bemoeienis zouden bijvoorbeeld gedeeltelijk een consequentie kunnen zijn van gedragsproblemen bij kinderen (Kerr, Stattin, Biesecker, \& Ferrer-Wreder, 2003). Verder is het zo dat, naast mogelijke kindeffecten, een 'derde variabele-verklaring' als het ware onder de gevonden verbanden ligt. Het zou bijvoorbeeld kunnen dat een moeilijk temperament of een lage sociabiliteit van het kind leidt tot verslechterende relaties op meerdere relationele domeinen, waaronder zowel die met ouders alsook later die met partners. Met andere woorden, het huidige onderzoek vergroot ons inzicht in de rol van ouder-kind interacties in de ontwikkeling van sociaal-emotionele problematiek, maar zegt niets over de oorzaken van eventueel negatieve ouder-kind interacties zelf.

Een onverwachte bevinding van het huidige onderzoek is dat het gespecificeerde model wel leek te gelden voor ontevredenheid met het leven, maar niet opging voor angst en depressieve stemmingen onder respondenten. Dat wil zeggen, de kwaliteit van de partnerrelatie was geen significante voorspeller voor angst en depressieve stemmingen over een periode van twaalf jaar. Een mogelijke verklaring hiervoor zou kunnen zijn dat de psychometrische kenmerken van deze vragenlijsten in één belangrijk opzicht verschillen van de vragenlijst waarmee we keken naar ontevredenheid met het leven. Op de laatstgenoemde vragenlijst hadden de scores een veel grotere spreiding dan op de vragenlijsten voor angst en depressieve stemmingen. Het concept 'ontevredenheid met het leven' reflecteert misschien dan ook een meer globale maat van symptomen van emotionele problematiek die meer gangbaar is in een algemene populatie, terwijl 'angst en depressiviteit' misschien ook meer 'klinisch relevante' symptomen meten die minder vaak voorkomen in een algemene populatie van volwassenen.

Met betrekking tot de ontwikkeling van partnerrelaties, maakten de resultaten duidelijk dat de kwaliteit van zulke relaties relatief stabiel was over een periode van twaalf jaar $[B=.51$ voor moeders, .54 voor vaders]. Dit is bijzonder, gegeven het feit dat de partnerrelaties die de respondenten hadden op 37-jarige leeftijd niet per se de relaties hoefden te zijn met de partners met wie zij een relatie hadden op 25-jarige leeftijd. Dat gegeven is indicatief voor een aantal zaken, waarvan de eerste is dat zodra mensen hun partnerrelaties in een negatief licht zien, het minder waarschijnlijk is dat ze relatief positieve percepties over hun relatie of hun partner ontwikkelen in de loop van de tijd (de correlationele aard van dit onderzoek staat ons alleen toe de termen 'negatief' en 'positief' in relatieve zin te gebruiken). Ten tweede verwijst het naar het fenomeen dat, nadat men een onbevredigende partnerrelatie heeft gehad, de kans groter wordt dat men opnieuw in een hieropvolgende, onbevredigende partnerrelatie terechtkomt. Nog een andere opvallende bevinding met betrekking tot de ontwikkeling van partnerrelaties en gevoelens ten aanzien van het andere geslacht, is dat deze laatste gevoelens niet voorspellend waren voor de kwaliteit van partnerrelaties in de jongvolwassenheid. De meest waarschijnlijke verklaring hier is dat een gebrek aan interesse in of zorgelijke houding ten aanzien van intieme relaties met leden van het andere geslacht in de adolescentie over het algemeen niet hoeven te betekenen dat een specifieke relatie met iemand van dat geslacht - waarbinnen de invloed van gedachten, gevoelens, en gedragingen van een specifieke persoon de meest belangrijke rol spelen - van lage kwaliteit is.

Er zijn enkele beperkingen in het huidige onderzoek waarmee rekening dient te worden gehouden. Ten eerste was het vanwege de beperkte steekproefomvang niet mogelijk om multigroep analyses uit te voeren, om zodoende een onderscheid te kunnen maken tussen mannen en vrouwen, of bijvoorbeeld tussen groepen met een 
verschillende socio-economische status. Verder moesten we onze maat van de affectieve kwaliteit van de vader-kind inderacties en de moeder-kind interacties baseren op één-item 'instrumenten'. Alhoewel we geloven dat dit voldoende is als maat voor de algemene affectieve kwaliteit van de ouder-kind band (zie ook Flouri \& Buchanan, 2002), zouden we dit concept wellicht nog betrouwbaarder hebben kunnen schatten als we de beschikking hadden gehad over een vragenlijst met meerdere items. Helaas was zo'n instrument niet voorhanden in het project in Solna. Ten slotte is het een nadeel dat deze gegevens uitsluitend beschikbaar waren voor een Zweedse steekproef. Alhoewel het waarschijnlijk lijkt dat de gegevens uit deze Noordwest-Europese steekproef wel toepasbaar zijn op de Nederlandse situatie, kan daarover niet met een volledige zekerheid uitspraken worden gedaan. Voorzichtigheid in de generalisatie van de resultaten blijft daarom geboden.

Ondanks deze beperkingen, lijkt het huidige onderzoek overtuigend bewijs te leveren voor een specifieke ontwikkelingssequentie van vroegkinderlijke interacties met ouders naar emotionele problematiek en een lage kwaliteit van partnerrelaties in de volwassenheid, waarbij een lage affectieve kwaliteit van ouder-kind relaties op jonge leeftijd gerelateerd is aan een hoger niveau van conflict en een lage kwaliteit van communicaties met ouders in de adolescentie, en deze op hun beurt een lagere kwaliteit van partnerrelaties in de jongvolwassenheid voorspellen, uiteindelijk uitmondend in een hogere ontevredenheid met het leven (maar niet in depressie of angst) tijdens de middenvolwassenheid, op 37-jarige leeftijd. Overbeek, G., Vermulst, A., Stattin, H., Ha, T., \& Engels, R. C. M. E. (2007). Parent-child relationships and social-emotional adjustment in adulthood. A birth-to-maturity prospective study, Kind en Adolescent, 28 (1), 4-19.

This study examined associations between childhood relationships with parents and later social-emotional development. Data were used from 212 children followed from birth until their $37^{\text {th }}$ birthday. SEM analyses demonstrated that negative parent-child bonds were indirectly related to low-quality partner relationships and dissatisfaction with life in adulthood (but not anxiety and depression), through conflictuous parent-adolescent communications and low-quality partner relationships in young adulthood.

Keywords: parent-child relationships, partner relationship quality, emotional adjustment.

\section{Literatuur}

Ainsworth, M. D. S. (1989). Attachments beyond infancy. American Psychologist, 44, 709-716.

Baldwin, M. W. (1992). Relational schemas and the processing of social information. Psychological Bulletin, 112, 461-484.

Baron, R. M., \& Kenny, D. A. (1986). The moderator-mediator variable distinction in social psychological research: Conceptual, strategic, and statistical considerations. Journal of Personality and Social Psychology, 51, 1173-1182.
Bretherton, I., \& Munholland, K. A. (1999). Internal working models in attachment relationships: A construct revisited. In J. Cassidy, \& P. R. Shaver (Eds.), Handbook of attachment: Theory, research, and clinical applications (pp. 89-111). New York: Guilford Press.

Brewin, C. R., Andrews, B., \& Gotlib, I. H. (1993). Psychopathology and early experience: A reappraisal of retrospective reports. Psychological Bulletin, 113, 82-98.

Brooks-Gunn, J., Phelps, E., \& Elder, G. H. (1991). Studying lives through time: Secondary data analyses in developmental psychology. Developmental Psychology, 27, 899-910.

Burbach, D. J., \& Bourduin, C. M. (1986). Parent-child relations and the etiology of depression: A review of methods and findings. Clinical Psychology Review, 6, 133-153.

Collins, N. L., Cooper, M. L., Albino, A., \& Allard, L. (2002). Psychosocial vulnerability from adolescence to adulthood: A prospective study of attachment style differences in relationship functioning and partner choice. Journal of Personality, 70, 965-1008.

Conger, R. D., Cui, M., Bryant, C. M., \& Elder, G. H. (2000). Competence in early adult romantic relationships: A developmental perspective on family influences. Journal of Personality and Social Psychology, 79, 224-237.

Cramer, D., \& Donachie, M. (1999). Psychological health and change in closeness in platonic and romantic relationships. Journal of Social Psychology, 139, 762-767.

Davila, J., Bradbury, T. N., \& Fincham, F. (1998). Negative affectivity as a mediator of the association between adult attachment and marital satisfaction. Personal Relationships, 5, 467-484.

Dozier, M., Stovall, K. C., \& Albus, K. E. (1999). Attachment and psychopathology in adulthood. In: J. Cassidy \& P.R. Shaver (Eds.), Handbook of attachment: Theory, research, and clinical applications (pp. 497-519). New York: Guilford.

Engels, R. C. M. E., Finkenauer, C., Meeus, W., \& Dekovic, M. (2001). Parental attachment and adolescents' emotional adjustment: The role of interpersonal tasks and social competence. Journal of Counseling Psychology, 48, 428-439.

Erikson, E. H. (1963). Childhood and society. New York: Norton.

Flouri, E., \& Buchanan, A. (2002). What predicts good relationships with parents in adolescence and partners in adult life: Findings from the 1958 British birth cohort. Journal of Family Psychology, 16, 186-198.

Franz, C. E., McLelland, D. C., \& Weineberger, J. (1991). Childhood antecedents of conventional social accomplishments in mid-life adults: A 35-year prospective study. Journal of Personality and Social Psychology, 60, 586-595.

Furman, W., \& Buhrmester, D. (1992). Age and sex in perceptions of networks of personal relationships. Child Development, 63, 103-115.

Gerlsma, C., Emmelkamp, P. M. G., \& Arrindell, W. A. (1990). Anxiety, depression, and perceptions of early parenting: A meta-analysis. Clinical Psychology Review, 10, 251-277.

Halverson, C. F. (1988). Remembering your parents: Reflections on the retrospective method. Journal of Personality, 56, 435-443.

Harris, T., Brown, G., \& Bifulco, A. (1986). Loss of parent in childhood and adult psychiatric disorder: The role of lack of adequate parental care. Psychological Medicine, 16, 641-659.

Hazan, C., \& Shaver, P. (1987). Romantic love conceptualized as an attachment process. Journal of Personality and Social Psychology, 52, 511-524.

Horowitz, A.V., McLaughlin, J., \& White, H. R. (1998). How the negative and positive aspects of partner relationships affect the mental health of young married people. Journal of Health and Social Behavior, 39, 124-136. 
Karlberg, P., Klackenberg, G., Engstrom, I., Klackenberg-Larsson, I., Liechtenstein, H., Stensson, J., \& Svennberg, I. (1968). The development of children in a Swedish urban community: A prospective longitudinal study. I. Introduction, design and aims of the study. Description of the sample. Acta Paediatrica Scandinavica, 187, 9-27.

Kerr, M., Stattin, H., Biesecker, G., \& Ferrer-Wreder, L. (2003). Relationships with parents and peers in adolescence. In M. A. Easterbrooks, \& R. M. Lerner (Eds.), Handbook of psychology: Developmental psychology, Vol. 6. (pp.395-419). New York: Wiley.

Laursen, B., \& Williams, V. A. (1997). Perceptions of interdependence and closeness in family and peer relationships among adolescents with and without romantic partners. In S. Shulman, \& W. A. Collins (Eds.), Romantic relationships in adolescence: Developmental perspectives (pp. 3-21). San Fransisco: Jossey-Bass.

Luthar, S. S., Cicchetti, D., \& Becker, B. (2000). The construct of resilience: A critical evaluation and guidelines for future work. Child Development, 71, 543-562.

MacKinnon, A. J., Henderson, A. S., \& Andrews, G. (1993). Parental 'affectionless control' as an antecedent to adult depression: A risk factor refined. Psychological Medicine, 23, 135-141.

Möller, K., \& Stattin, H. (2001). Are close relationships in adolescence linked with partner relationships in midlife? A longitudinal, prospective study. International Journal of Behavioral Development, 25, 69-77.

Muthén, L. K., \& Muthén, B. O. (2001). Mplus User's Guide (2 $2^{\text {nd }}$ edition). Los Angeles, CA: Muthén \& Muthén.
Neugarten, B. L., Havighurst, R. J., \& Tobin, S. S. (1961). The measurement of life satisfaction. Journal of Gerontology, 16, 134-143.

O'Connor, T. G. (2003). Early experiences and psychological development: Conceptual questions, empirical illustrations, and implications for intervention. Development and Psychopatho$\log y, 15,671-690$.

Overbeek, G., Vollebergh, W. A. M., Engels, R. C. M. E., \& Meeus, W. H. J. (2003). Parental attachment and romantic relationships: Links with emotional disturbance during late adolescence. Journal of Counseling Psychology, 50, 28-39.

Seiffge-Krenke, I. (2003). Testing theories of romantic development from adolescence to young adulthood: Evidence of a developmental sequence. International Journal of Behavioral Development, 27, 519-531.

Sroufe, L. A., Carlson, E. A., Levy, A. K., \& Egeland, B. (1999). Implications of attachment theory for developmental psychopathology. Development and Psychopathology, 11, 1-13.

Stattin, H., \& Klackenberg, G. (1992). Discordant family relations in intact families: Developmental tendencies over 18 years. Journal of Marriage and Family, 54, 940-956.

Steinberg, L., Lamborn, S. D., Darling, N., Mounts, N. S., \& Dornbusch, S. M. (1994). Over-time changes in adjustment and competence among adolescents from authoritative, authoritarian, indulgent, and neglectful families. Child Development, 65, 754-770.

Veit, C. T., \& Ware, J. E. Jr. (1983). The structure of psychological distress and well-being in general populations. Journal of Consulting and Clinical Psychology, 51, 730-742. 